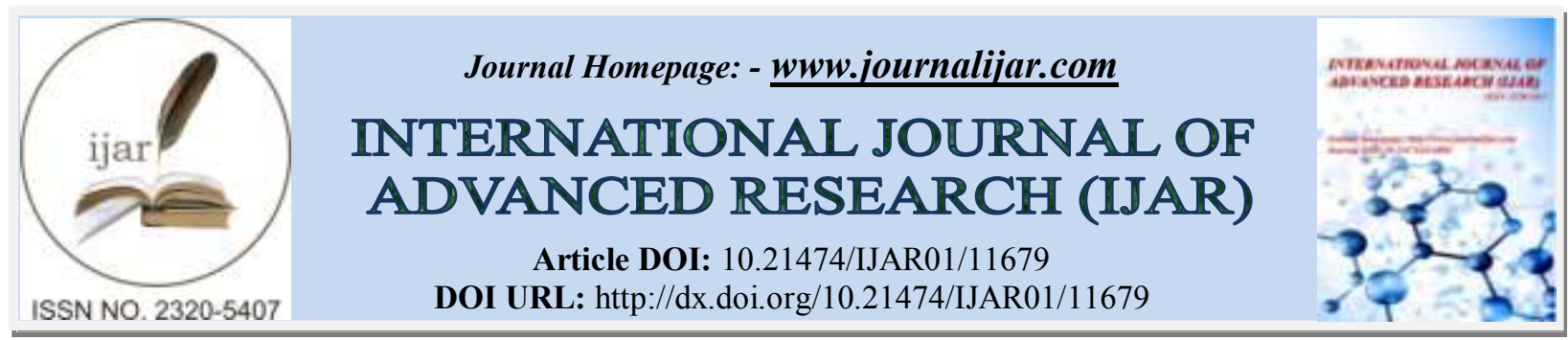

RESEARCH ARTICLE

\title{
STUDY ON DRINKING WATER QUALITY ANALYSIS FOR PHYSIOCHEMICAL AND MICROBIAL PARAMETERS
}

Dhanush N. Begur

\section{Manuscript Info}

Manuscript History

Received: 10 July 2020

Final Accepted: 14 August 2020

Published: September 2020

\section{Abstract}

Study aims to analyze the physicochemical and microbial parameters of water samples collected from places in and around Mangalore, Karnataka, India and accesses the objectives for physicochemical parameters of samples, for biological parameters and to compare and ensure safe water quality standards for human consumption with ISI(International standard Institute)specification for drinking water (portable water). There are 3 parts, first part consists of Introduction to the research, second consists of methods and methodology used for various tests and third consists of the final results obtained with discussions and conclusion to end with.

Copy Right, IJAR, 2020,. All rights reserved.

\section{Introduction:-}

Biological diversity - or biodiversity - is the term given to the variety of species on Earth. Biodiversity is shaped by natural processes and, increasingly, by the influence of humans. It forms the web of life of which we are an integral part and upon which we depend. This diversity depends on the wide variety of plants, animals and microorganisms. Microbes live on this planet since more than three billion of years and their capability to adapt to several environments make them still the "highlanders", as they possess metabolic versatility which ensure them a key-role in biogeochemical processes. At the same time microbes in natural ecosystems receive little attention; they are largely ignored even by most professionals and are virtually unknown to the public except in pathogens plus few other minor areas. Yet, the functioning of whole biosphere depends absolutely on the activities of the microbial world (Parnell et al., 2009).

Water microbiology is concerned with the microorganisms that live in water, or can be transported from one habitat to another by water. Water can support the growth of many types of microorganisms. This can be advantageous. For example, the growth of some bacteria in contaminated water can help digest the poisons from the water. However, the presence of other disease-causing microbes in water is unhealthy and even life threatening. For example, bacteria that live in the intestinal tracts of humans and other warm-blooded animals, such as E. coli, Salmonella, Shigella, and Vibrio, can contaminate water if feces enter the water. Contamination of drinking water with a type of Escherichia coli known as O157:H7 can be fatal. The contamination of the municipal water supply of Walkerton, Ontario, Canada in the summer of 2000 by strain O157:H7 sickened 2,000 people and killed seven people (Chapelle et al., 2000). The intestinal tract of warm-blooded animals also contains viruses that can contaminate water and cause disease. Examples include rotavirus, enteroviruses, and coxsackievirus. Another group of microbes of concern in water microbiology are protozoa. The two protozoa of the most concern are Giardia and Cryptosporidium. They live normally in the intestinal tract of animals such as beaver and deer. Giardia and Cryptosporidium form dormant and hardy forms called cysts during their life cycles. The cyst forms are resistant to chlorine, which is the most popular form of drinking water disinfection, and can pass through the filters used in many water treatmentplants. If ingested 
in drinking water they can cause debilitating and prolonged diarrhoea in humans, and can be life threatening to those people with impaired immune systems. Cryptosporidium contamination of the drinking water of Milwaukee, Wisconsin with in 1993 sickened more than 400,000 people and killed 47 people.

Many microorganisms are found naturally in freshwater. These include bacteria, cyanobacteria, protozoa, algae, and tiny animals such as rotifers. These can be important in the food chain that forms the basis of life in the water. For example, the microbes called cyanobacteria can convert the energy of the sun into the energy it needs to live. The plentiful numbers of these organisms in turn are used as food for other life. The algae that thrive in water are also an important food source for other forms of life.

The region of a water body near the shoreline (the littoral zone) is well lighted, shallow, and warmer than other regions of the water. Photosynthetic algae and bacteria that use light as energy thrive in this zone. Further away from the shore is the limnetic zone. Photosynthetic microbes also live here. As the water deepens, temperatures become colder and the oxygen concentration and light in the water decrease. Now, microbes that require oxygen do not thrive. Instead, purple and green sulfur bacteria, which can grow without oxygen, dominate. Finally, at the bottom of fresh waters (the benthic zone), few microbes survive. Bacteria that can survive in the absence of oxygen and sunlight, such as methane producing bacteria, thrive (Chapelle et al., 2000).

Water can also be an ideal means of transporting microorganisms from one place to another. For example, the water that is carried in the hulls of ships to stabilize the vessels during their ocean voyages is now known to be a means of transporting microorganisms around the globe. One of these organisms, a bacterium called Vibrio cholerae, causes life threatening diarrhoea in humans.

Drinking water is usually treated to minimize the risk of microbial contamination. The importance of drinking water treatment has been known for centuries. For example, in pre-Christian times the storage of drinking water in jugs made of metal was practiced. Now, the anti-bacterial effect of some metals is known. Similarly, the boiling of drinking water, as a means of protection of water has long been known.

Chemicals such as chlorine or chlorine derivatives has been a popular means of killing bacteria such as Escherichia coli in water since the early decades of the twentieth century. Other bacteria-killing treatments that are increasingly becoming popular include the use of a gas called ozone and the disabling of the microbe's genetic material by the use of ultraviolet light. Microbes can also be physically excluded from the water by passing the water through a filter. Modern filters have holes in them that are so tiny that even particles as miniscule as viruses can be trapped (Madigan et al., 2000).

An important aspect of water microbiology, particularly for drinking water, is the testing of the water to ensure that it is safe to drink. Water quality testing can be done in several ways. One popular test measures the turbidity of the water. Turbidity gives an indication of the amount of suspended material in the water. Typically, if material such as soil is present in the water then microorganisms will also be present. The presence of particles even as small as bacteria and viruses can decrease the clarity of the water. Turbidity is a quick way of indicating if water quality is deteriorating, and so if action should be taken to correct the water problem.

In many countries, water microbiology is also the subject of legislation. Regulations specify how often water sources are sampled, how the sampling is done, how the analysis will be performed, what microbes are detected, and the acceptable limits for the target microorganisms in the water sample. Testing for microbes that cause disease (i.e., Salmonella typhymurium and Vibrio cholerae) can be expensive and, if the bacteria are present in low numbers, they may escape detection. Instead, other more numerous bacteria provide an indication of faecal pollutionof the water. Escherichia coli (E. coli) have been used as an indicator of faecal pollution for decades. The bacterium is present in the intestinal tract in huge numbers, and is more numerous than the disease-causing bacteria and viruses. The chances of detecting E. coli are better than detecting the actual disease causing microorganisms. Escherichia coli also had the advantage of not being capable of growing and reproducing in the water (except in the warm and food-laden waters of tropical countries). Thus, the presence of the bacterium in water is indicative of recent faecal pollution. Finally, Escherichia coli can be detected easily and inexpensively (Madigan et al., 2000). 
The importance of the provision of a wholesome supply of drinking water has been recognised since at least the times of the Romans with major advances being made during the nineteenth century. The provision of safe drinking water is one of the most important steps that can be taken to improve the health of a community by preventing the spread of water-borne disease. The maintenance of a sufficient supply of wholesome drinking water is a complex undertaking in which individuals from many disciplines have a role.

\section{Legislation and water quality standards for public water supplies}

The new European Directive for drinking water prescribes standards for the quality of drinking water, water offered for sale in bottles or containers and water for use in food production undertakings. The Directive specifies two types of parameter values, namely mandatory and non-mandatory. Mandatory standards, covering 28 microbiological and chemical parameters for mains water, are essential for health and the environment, and have to be met by specified dates. Non-mandatory indicator values, covering 20 further microbiological, chemical and physical parameters are prescribed for monitoring purposes. Any contravention of an indicator value must be investigated, but remedial action need be taken only where there is a risk to public health. The Water Industry Act, the Water Supply (Water Quality) Regulations and the Private Water Supplies Regulations transpose the Directive into English law. The Act places a duty on water companies to supply only water that is wholesome at the time of supply. The Act also creates a criminal offence of supplying water that is unfit for human consumption. Wholesomeness is defined by reference to the prescribed concentrations or values and other requirements. Prescribed concentrations or values are specified for microbiological, chemical and physical parameters. National legislation includes some standards and requirements in addition to those required by the Directive. All water covered by the regulations must be microbiologically wholesome. Prescribed concentrations or values for microbiological parameters rely on well proven indicator organisms, such as coliform bacteria, Escherichia coli, Enterococci, Clostridium perfringens, and colony counts. In addition to meeting standards, water must not contain any micro-organism (other than a parameter) or parasite at a concentration which would constitute a potential danger to human health

\section{Materials And Methods:-}

Materials

The chemicals used in the study were of analytical grade procured from HiMedia and Merck and Co. And Sigma Aldrich

\section{Materials used \\ Media}

1. Nutrient agar

Composition: Peptic digest of animal tissue $-10 \mathrm{~g} / \mathrm{L}$, Beef extract $-10 \mathrm{~g} / \mathrm{L}$, Sodium chloride $-5 \mathrm{~g} / \mathrm{L}$, Agar $-15 \mathrm{~g} / \mathrm{L}$, Final $\mathrm{pH}\left(\right.$ at $\left.25^{\circ} \mathrm{C}\right) 7.2$

2. Nutrient broth

Composition: Peptone $-5 \mathrm{~g} / \mathrm{L}$, Sodium chloride $-5 \mathrm{~g} / \mathrm{L}$, Meat extract $\mathrm{B}-1.50 \mathrm{~g} / \mathrm{L}$, Yeast extract $-1.5 \mathrm{~g} / \mathrm{L}$, Final $\mathrm{pH}$ (at $\left.25^{\circ} \mathrm{C}\right) 7.4$

3. Potato dextrose agar

Composition: Potatoes infusion from - 200g/L, Dextrose $-20 \mathrm{~g} / \mathrm{L}$, Agar $-15 \mathrm{~g} / \mathrm{L}$, Final pH (at $\left.25^{\circ} \mathrm{C}\right) 5.6$

4. EMB agar, Lactose Broth (single and double strength)

5. Tryptone glucose extract agar

\section{Equipment's used}

Autoclave, Laminar air flow, Incubator, Hot air oven, Water bath

\section{Consumables}

Test tubes, beaker, measuring cylinder, Petri plates, BOD bottles, Conical flasks, Burettes, Tips, Pipette

Chemicals used

Alcohol, Methanol, KOH, KI, $\mathrm{Na}_{2} \mathrm{~S}_{2} \mathrm{O} 3, \mathrm{NaN}_{3}, \mathrm{NaOH}$, EDTA (0.01M), Buffers, $\mathrm{MnSO}_{4}$, Alkali-iodide-azide-500g

\section{Reagents and standards}

1. Phosphate buffer: Dissolve $8.5 \mathrm{~g} \mathrm{KH}_{2} \mathrm{PO}_{4}, 21.75 \mathrm{~g} \mathrm{~K}_{2} \mathrm{HPO}_{4}, 33.5 \mathrm{~g} \mathrm{Na}_{2} \mathrm{HPO}_{4} .7 \mathrm{H}_{2} \mathrm{O}$ in distilled water and dilute to $1000 \mathrm{~mL}$. The $\mathrm{pH}$ should be 7.2 without further adjustment. Discard reagent if there is any sign of biological growth. 
2. Magnesium sulphate: Dissolve $22.5 \mathrm{~g} \mathrm{MgSO}_{4} \cdot 7 \mathrm{H}_{2} \mathrm{O}$ in about $700 \mathrm{~mL}$ of distilled water and dilute to $1 \mathrm{Litre}$.

3. Calcium chloride: Dissolve $27.5 \mathrm{~g}$ anhydrous $\mathrm{CaCl}_{2}$ in about $7000 \mathrm{~mL}$ of distilled water and dilute to $1 \mathrm{Litre}$.

4. Ferric chloride: Dissolve $0.25 \mathrm{~g} \mathrm{FeCl}_{3} \cdot 6 \mathrm{H}_{2} \mathrm{O}$ in about $700 \mathrm{~mL}$ of distilled water and dilute to $1 \mathrm{~L}$.

5. Sodium sulphate solution $0.025 \mathrm{~N}$ : Dissolve $1.575 \mathrm{~g} \mathrm{Na}_{2} \mathrm{SO}_{3}$ in distilled water and dilute to $1000 \mathrm{~mL}$. Solution should be prepared daily.

6. Acid and Alkali solutions $1 \mathrm{~N}$ : Prepare $1 \mathrm{~N} \mathrm{H}_{2} \mathrm{SO}_{4}$ and $1 \mathrm{~N} \mathrm{NaOH}$ or neutralization of caustic or acidic samples.

7. Nitrification inhibitor: 2-chloro-6-(trochloromethyl) pyridine [Nitrification inhibitor 2570-24 (2.2\% TCMP)]

8. Glucose-glutamic acid solution: Dry reagent grade glucose and glutamic acid at $103^{\circ} \mathrm{C}$ for $1 \mathrm{~h}$. Dissolve $150 \mathrm{mg}$ glucose and $150 \mathrm{mg}$ glucose acid in distilled water and dilute to $1000 \mathrm{~mL}$. Prepare fresh immediately before use.

\section{Indicators used}

1. Methyl orange indicator

2. Phenolphthalein indicator

3. Erichrome black $\mathrm{T}$ indicator

4. Starch indicator

\section{Samples used}

1. Well water

2. Bore well water

3. Maroli water sample

4. Kadri water sample

\section{Methodology:-}

\section{Study area:}

1. Well water

2. Bore well water

3. Maroli water sample, Maroli, Mangaluru, Karnataka

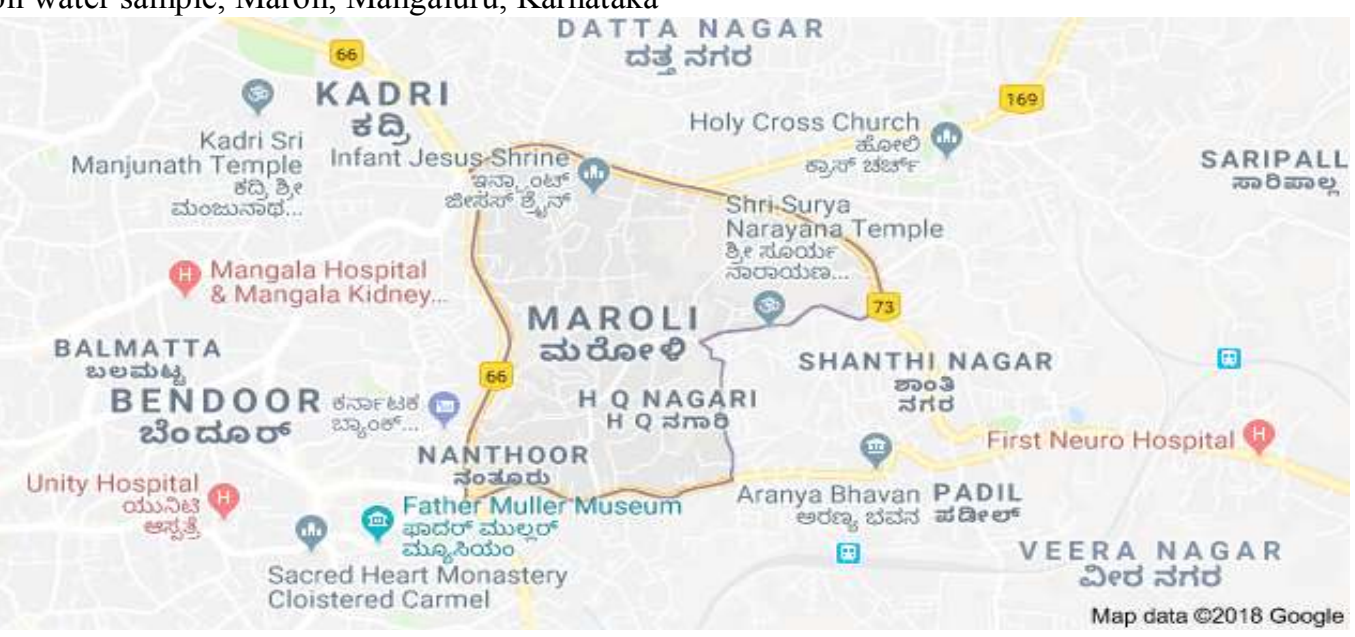

Kadri water sample, Kadri, Mangaluru, Karnataka

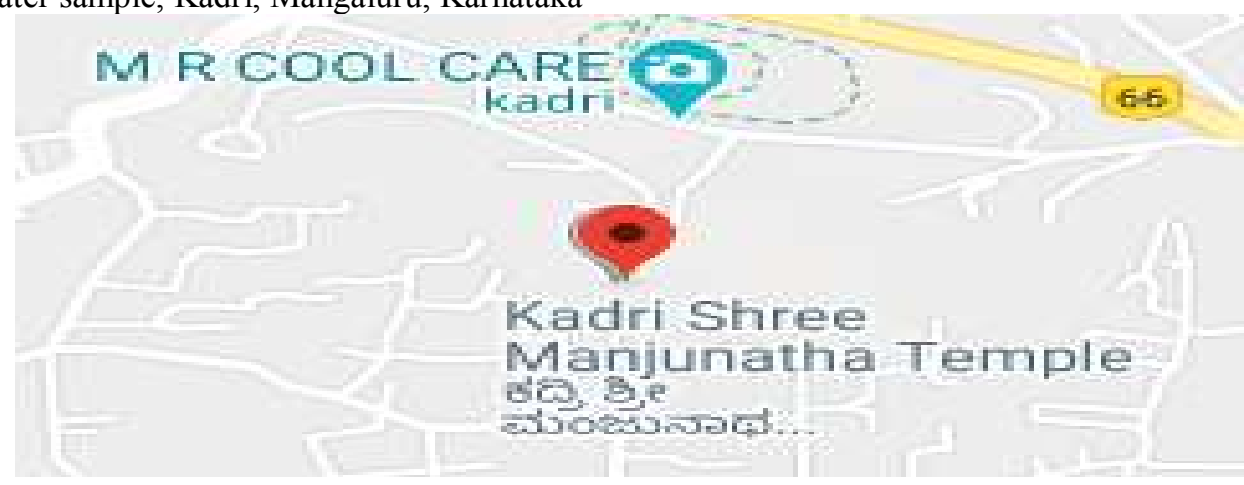




\title{
Sample collection:
}

Samples were collected in sterile containers from above spots. Collection of water samples were made for the study of physical, chemical parameters.

The temperature and $\mathrm{pH}$ were noted on the spot and remaining factors were analysed in the laboratory without lapse of much time.

\section{Analysis of Physicochemical parameters}

Colour

Pure water has no colour. The presence of some acids, weeds or industrial effluents may cause colour change of drinking water.

\section{Determination of temperature}

Temperature is noted at the time of sampling with a thermometer (Trideviand Goel, 1986).

Determination of pH by electrometric method (Trideviand Goel, 1986).

Principle: The basic principle of electrometric $\mathrm{pH}$ measurement is determination of the activity of the hydrogen ion by potentiometric measurements using a standard hydrogen electrode usually glass electrode is used. The electromotive force (emf) produced in the glass electrode system varies linearly with $\mathrm{pH}$

\section{Procedure:}

The electrode was thoroughly washed with distilled water and then with the sample

\author{
$\downarrow$
}

The electrode was dipped in the sample and reading was noted down

\subsubsection{Determination of Carbon dioxide (Trivedi and Goel, 1986)}

Procedure:

Take $100 \mathrm{ml}$ of the sample in a conical flask

$\downarrow$

Add 3-4 drops of phenolphthalein indicator, if the colour changes pink free $\mathrm{CO} 2$ is absent

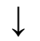

Note down the burette reading, suing the formula. If it remains colourless then iot is titrated against $0.05 \mathrm{~N} \mathrm{NaOH}$ till pink colour appears.

$$
\text { Free CO2 } \mathrm{mg} / L=\frac{A \times N \times 1000 \times 44}{\text { Volume of the sample }}
$$

Where,

A- Volume of $\mathrm{NaOH}$ added

B- N- normality of $\mathrm{NaOH}$

\section{Hardness of water}

Principle

EDTA (Ethylenediamine tetra acetic acid) forms colorless stable complexes with $\mathrm{Ca} 2+$ and $\mathrm{Mg} 2+$ ions present in water at $\mathrm{pH} 9-10$. To maintain the $\mathrm{pH}$ of the solution at 9-10, buffer solution $\left(\mathrm{NH}_{4} \mathrm{Cl}+\mathrm{NH}_{4} \mathrm{OH}\right)$ is used. Erichrome Black-T (E.B.T) is used as an indicator. The sample of hard water must be treated with buffer solution and EBT indicator which forms unstable, wine-red coloured complex with $\mathrm{Ca} 2+$ and $\mathrm{Mg} 2+$ present in water. (https://www.cutm.ac.in/pdf/Env\%20Engg\%20Lab\%20Manual.pdf)

\section{Procedure:}

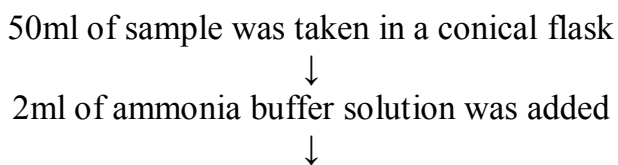

The above solution was titrated aganist $0.02 \mathrm{~N}$ EDTA solution using Eriochrome black-T as indicator

The burette rerading was noted when the colour changes from red to blue 
$\downarrow$

Hardness can be calculated using the formula (Tridevi and Goel, 1986)

$$
\text { Hardness } \mathrm{mg} / \mathrm{l}=\frac{\text { burette reading } \times 1000}{\text { vol.of sample taken }}
$$

Alkalinity (Trivedi and Goel, 1986)

Procedure:

Take $100 \mathrm{ml}$ of the sample in a conical flask

$\downarrow$

Add 2-3 drops of phenolphthalein indicator, if the remains colourless, alkalinity is absent

If contents turns pink, titrate with $0.1 \mathrm{~N} \mathrm{HCl}$ till colour disappears

Note down the burette reading for phenolphthalein alkalinity

$\downarrow$

Now add 2 drops of methyl orange indicator and titrate and titrate further till the colour changes from pale yellow to orange/pink

\section{Analysis of Biological parameters \\ Dissolved oxygen \\ Principle}

It is based on oxidation of potassium iodide. The liberated iodine is titrated against standard hypo solution using starch as a final indicator. Since oxygen in water is in molecular state and not capable to react with KI, an oxygen carrier manganese hydroxide is used to bring about the reaction between $\mathrm{KI}$ and $\mathrm{O}_{2}$. Manganous hydroxide is produced by the action of potassium hydroxide and manganous sulphate.

\section{Procedure}

1. Take $500 \mathrm{ml}$ of water in a D.O bottle.

2. Add $10 \mathrm{ml}$ of alkaline $\mathrm{KI}$ and $10 \mathrm{ml}$ of $\mathrm{MnSO} 4$ into it.

3. Stopper the bottle and shake it well.

4. Keep the bottle in dark for 5 min and add Conc. $\mathrm{H}_{2} \mathrm{SO}_{4}$ till the brown precipitates are dissolved.

5. Take $100 \mathrm{ml}$ of the above solution in a conical flask. Titrate against hypo till the colour changes to light Yellow.

6. Add 3-4 drops of starch in to it and the colour changes to blue.

7. The blue colour solution is titrated against hypo solution till blue colour disappeared.

8. This is end point of the titration. Repeat this process till to get three concordant reading. (https://www.cutm.ac.in/pdf/Env\%20Engg\%20Lab\%20Manual.pdf)

DO $\mathrm{mg} / \mathrm{L}=\frac{B R \times 1000 \times N \times 8}{\text { VOL.OF SAMPLE }}$

Where, N - normality of titrant used (Aneja, 2004)

\section{MPN (Most Probable Number) test \\ Principle}

Since human fecal pathogens vary in kind (viruses, bacteria, protozoa) and in number, it would be impossible to test each water sample for each pathogen. Instead, it is much easier to test for the presence of non-pathogenic intestinal organisms such as E. coli. E. coli is a normal inhabitant of the intestinal tract and is not normally found in fresh water. Therefore, if it is detected in water, it can be assumed that there has been faecal contamination of the water.

\section{Standard water analysis \\ Presumptive test}

In the presumptive test, a series of lactose broth tubes are inoculated with measured amounts of the water sample to be tested. The series of tubes may consist of three or four groups of three, five or more tubes. The more tubes utilized, the more sensitive the test. Gas production in any one of the tubes is presumptive evidence of the presence of coliforms. The most probable number (MPN) of coliforms in $100 \mathrm{ml}$ of the water sample can be estimated by the number of positive tubes. 


\section{The Confirmed Test}

In order to confirm the presence of coliforms, it is necessary to inoculate EMB (eosin methylene blue) agar plates from a positive presumptive tube. The methylene blue in EMB agar inhibits Gram positive organisms and allows the Gram negative coliforms to grow. Coliforms produce colonies with dark centres. E. coli and E. aerogenes can be distinguished from one another by the size and colour of the colonies. E. coli colonies are small and have a green metallic sheen, whereas E. aerogenes forms large pinkish colonies.

\section{The Completed Test}

The completed test is made using the organisms which grew on the confirmed test media. These organisms are used to inoculate a nutrient agar slant and a tube of lactose broth. After 24 hours at $37^{\circ} \mathrm{C}$, the lactose broth is checked for the production of gas, and a Gram stain is made from organisms on the nutrient agar slant. If the organism is a Gram negative, non-spore-forming rod and produces gas in the lactose tube, then it is positive that coliforms are present in the water sample.

(https://www.cutm.ac.in/pdf/Env\%20Engg\%20Lab\%20Manual.pdf)

\section{Procedure}

\section{Presumptive Test}

1. Take a water sample (dilute as instructed in some cases) and inoculate three tubes of lactose broth with $10 \mathrm{ml}$, three tubes with $1.0 \mathrm{ml}$ and three tubes with $0.1 \mathrm{ml}$.

2. Incubate all tubes at $37 \mathrm{oC}$ for 24 hours.

3. Observe the number of tubes at each dilution that show gas production in $24 \mathrm{hrs}$. Record results

4. Reincubate for an additional 24 hours at $37^{\circ} \mathrm{C}$.

\section{Confirmed Test}

1. Inoculate an EMB plate with material from a tube containing gas.

2. Invert and incubate the plate at $37^{\circ} \mathrm{C}$ for 24 hours.

3. Observe EMB agar plates. A positive confirmed test is indicated by small colonies with dark centres and a green metallic sheen (E. coli). Record results.

\section{Completed Test}

1. Inoculate a lactose broth tube and a nutrient agar slant with organisms from the EMB plate.

2. Incubate the broth tube and agar slant at $37^{\circ} \mathrm{C}$ for 24 hours.

3. Check for gas production in the lactose broth tube.

4. Make a Gram stain from the organisms on the nutrient agar slant.

5. Record results(https://www.cutm.ac.in/pdf/Env\%20Engg\%20Lab\%20Manual.pdf)

\section{Biological Oxygen Demand (BOD) of water sample Principle}

This test measures the oxygen utilized for the biochemical degradation of organic material (carbonaceous demand) and oxidation of inorganic material such as sulphides and ferrous ions during a specified incubation period. It also measures the oxygen used to oxidize reduced forms of nitrogen (nitrogenous demand) unless their oxidation is prevented by an inhibitor. Temperature effects are held constant by performing a test at fixed temperature. The methodology of BOD test is to compute a difference between initial and final DO of the samples incubation. A mixed group of microorganisms should be present in the sample; otherwise, the sample has to be seeded. Generally, temperature is controlled at $20^{\circ} \mathrm{C}$ and the test is conducted for 5 days, as 70 to $80 \%$ of the carbonaceous wastes are oxidized during this period. (https://www.cutm.ac.in/pdf/Env\%20Engg\%20Lab\%20Manual.pdf)

\section{Procedure}

1. Preparation of dilution water:

2. The source of dilution water may be distilled water, tap or receiving-stream water free of biodegradable organics and bioinhibitory substances such as chlorine or heavy metals.

3. Aerate the required volume of dilution water in a suitable bottle by bubbling clean filtered compressed air for sufficient time to attain DO saturation at room temperature or at $20^{\circ} \mathrm{C} / 27^{\circ} \mathrm{C}$. Before use stabilize the water at $20^{\circ} \mathrm{C} / 27^{\circ} \mathrm{C}$.

4. Add $1 \mathrm{~mL}$ each of phosphate buffer, magnesium sulphate, and calcium chloride and ferric chloride solutions in that order for each Litre of dilution water. Mix well. Quality of dilution water may be checked by incubating a 
BOD bottle full of dilution water for 5 days at $20^{\circ} \mathrm{C}$ for 3 days at $27^{\circ} \mathrm{C}$. DO uptake of dilution water should not be more than $0.2 \mathrm{mg} / \mathrm{L}$ and preferable not more than $0.1 \mathrm{mg} / \mathrm{L}$.

5. Determine BOD of the seeding material. This is seed control. From the value of seed control determine seed DO uptake. The DO uptake of seeded dilution water should be between $0.6 \mathrm{mg} / \mathrm{L}$ and $1 \mathrm{mg} / \mathrm{L}$

\section{Sample preparation:}

1. Neutralize the sample to $\mathrm{pH} 7$, if it is highly acidic or alkaline.

2. The sample should be free from residual chlorine. If it contains residual chlorine remove it by using $\mathrm{Na} 2 \mathrm{~S} 2 \mathrm{O} 3$ solution as described below.

3. Take $50 \mathrm{~mL}$ of the sample and acidify with addition of $10 \mathrm{~mL} 1+1$ acetic acid. Add about $1 \mathrm{~g} \mathrm{Kl}$. Titrate with $0.025 \mathrm{~N} \mathrm{Na}_{2} \mathrm{~S}_{2} \mathrm{O}_{3}$, using starch indicator. Calculate the volume of $\mathrm{Na}_{2} \mathrm{~S}_{2} \mathrm{O}_{3}$ required per Litre of the sample and accordingly add to the sample to be tested for BOD.

4. Certain industrial wastes contain toxic metals, e.g. planting wastes. Such samples often require special study and treatment.

5. Bring samples to $20 \pm 1^{\circ} \mathrm{C}$ before making dilutions

6. If nitrification inhibition is desired, add $3 \mathrm{mg}$ 2-chloro-6-(trichloromethyl) pyridine (TCMP) to each $300 \mathrm{~mL}$ bottle before capping or add sufficient amount to the dilution water to make a final concentration of $30 \mathrm{mg} / \mathrm{L}$. Note the use of nitrogen inhibition in reporting results.

7. Samples having high DO contents, $\mathrm{DO} \geq 9 \mathrm{mg} / \mathrm{L}$ should be treated to reduce the DO content to saturation at $20^{\circ} \mathrm{C}$. Agitate or aerate with clean, filtered compressed air.

8. Dilution of sample: Dilutions that result in a residual DO of at least $1 \mathrm{mg} / \mathrm{L}$ and DO uptakes of at least $2 \mathrm{mg} / \mathrm{L}$ produce reliable results. Make several dilutions of the pretreated sample so as to obtain about $50 \%$ depletion of DO or DO uptake of $2 \mathrm{mg} / \mathrm{L}$. Prepare dilutions as follows:

9. Siphon out half the required volume of seeded dilution water in a graduated cylinder or volumetric flask without entraining air. Add the desired quantity of mixed sample and dilute to the appropriate volume by siphoning dilution water. Mix well with plunger type mixing rod to avoid entraining air.

\section{Sample processing:}

1. Siphon the diluted or undiluted sample in three labeled bottles and stopper immediately.

2. Keep 1 bottle for determination of the initial DO and incubate 2 bottles at $20^{\circ} \mathrm{C}$ for 3days. See that the bottles have a water seal.

3. Prepare a blank in triplicate by siphoning plain dilution water (without seed) to measure the $\mathrm{O} 2$ consumption in dilution water. d. Also prepare a seed blank in triplicate to measures BOD of seed for correction of actual BOD.

4. Determine DO in a BOD test can in the blank on initial day and end of incubation period by Winkler method as described for DO measurement.

5. DO estimation in a BOD test can also be done by membrane electrodes. A DO probe with a stirrer is used to determine initial and final DO after incubation in BOD samples. The semi permeable membrane provided in the DO probe acts as a diffusion barrier against impurities between sensing element and sample

\section{Calculations}

Calculate BOD of the sample as follows:

a. When dilution water is not seeded

$\mathrm{BOD}$ as $\mathrm{O} 2 \mathrm{mg} / \mathrm{L}=(\mathrm{D} 1-\mathrm{D} 2) \times 100 / \%$ dilution

b. When dilution is seeded

BOD O2 mg/L = [(D1 - D2) $-(\mathrm{B} 1-\mathrm{B} 2)]$ x $100 / \%$ dilution

c. When material is added to sample or to seed control

BOD O2 mg/L $=\left[(\mathrm{D} 1-\mathrm{D} 2)-\left(\mathrm{B} 1^{\prime} \times \mathrm{B} 2^{\prime}\right]\right.$ x $\mathrm{F} \times 100 / \%$ dilution

where,

$\mathrm{D} 1=\mathrm{DO}$ of sample immediately after preparation, $\mathrm{mg} / \mathrm{L}$

$\mathrm{D} 2=\mathrm{DO}$ of sample after incubation period, $\mathrm{mg} / \mathrm{L}$

$\mathrm{B} 1=\mathrm{DO}$ of blank (seeded dilution water) before incubation, $\mathrm{mg} / \mathrm{L}$

$\mathrm{B} 2=\mathrm{DO}$ of blank (seeded dilution water) after incubation, $\mathrm{mg} / \mathrm{L}$

$\mathrm{F}=$ ratio of seed in diluted sample to seed in seed control (Vol. Of seed in diluted sample / Vol. of seed in seed control)

$\mathrm{B} 1^{\prime}=\mathrm{DO}$ of seed control before incubation, $\mathrm{mg} / \mathrm{L}$

$\mathrm{B} 2^{\prime}=\mathrm{DO}$ of seed control after incubation, $\mathrm{mg} / \mathrm{L}$ 
In calculations, do not make corrections for DO uptake in dilution water. (https://www.cutm.ac.in/pdf/Env\%20Engg\%20Lab\%20Manual.pdf)

\section{Chemical Oxygen Demand (COD) of the water sample Principle}

COD is the measure of oxygen consumed during the oxidation of the oxidisable organic matter by a strong oxidising agent. Potassium dichromate in the presence of sulphuric acid is generally used as an oxidising agent. The excess of potassium dichromate was titrated against sodium thiosulphate using starch as an indicator. The amount of potassium dichromate used is proportional to the oxidisable organic matter present in the sample.

Procedure

$50 \mathrm{ml}$ each of the sample were taken in three conical flask

$\downarrow$

Simultaneously three distilled water blank standards were also taken

$\downarrow$

$5 \mathrm{ml}$ of $\mathrm{K}_{2} \mathrm{Cr}_{2} \mathrm{O}_{7}$ solution was added to each of the six flasks

$\downarrow$

Flasks were kept in the water bath at $100^{\circ} \mathrm{C}$ for $1 \mathrm{hr}$

Samples were allowed to cool for $10 \mathrm{mins}$

$\downarrow$

$5 \mathrm{ml}$ of potassium iodide was added to each of the flasks

$\downarrow$

$10 \mathrm{ml}$ of $\mathrm{H} 2 \mathrm{SO} 4$ was added to all the flasks

$\downarrow$

The contents of each flasks was titrated against $0.1 \mathrm{M}$ sodium thiosulpahte until the appearance of pale yellow colour $\downarrow$

$1 \mathrm{ml}$ of starch solution was added, for the appearance of the blue colour

$\downarrow$

Again it was titrated against the titrant until the blur colour disappears completely

(Tridevi and Goel, 1986)

COD of sample in $\mathrm{mg} / \mathrm{L}=\frac{8 \times C \times(B-A)}{S}$

Where, $\mathrm{C}=$ concentration of titrant $(\mathrm{ml})$

$\mathrm{A}=$ volume of titrant used for blank (ml)

$\mathrm{B}=$ volume of titrant used for sample $(\mathrm{ml})$

$\mathrm{S}=$ volume of water sample taken (ml) (Aneja, 2004)

\section{The Standard Plate Count (SPC)}

The water microorganisms have great variations for their physiological requirements. No single medium, with similar physiological conditions etc. are ideal for them. The standard plate count method is recommended for water analysis. For the accurate analysis, it is recommended to plate the two dilutions in duplicate and take out the average. Generally, a plate containing between 30 and 300 colonies is selected for counting. (Dubey et al., 2008)

\section{Procedure:}

1. Liquefy two tubes containing tryptone glucose extract agar

2. Pour and cool to $450 \mathrm{C}$ transfer water sample $(1 \mathrm{ml})$ to each of two sterile petridish

3. Pour the medium into the dishes, shake gently and incubate at $350 \mathrm{C}$ for $24 \mathrm{hrs}$

\section{Result:-}

1. Bacterial colonies appear on the surface of the medium.

2. Count the colonies by colony counter and record the average number of colonies of all plates 
ISI (Indian Standard Institute) specification for drinking water

ISI specification for drinking water (potable water) has been give below

Table 2.2.2.6:- ISI (Indian Standard Institute) specification for drinking water.

\begin{tabular}{|c|c|c|}
\hline Sl. No. & Characteristics & Desirable limit \\
\hline 1 & Colour & $5 \mathrm{mg} / \mathrm{L}$ \\
\hline 2 & Odour & Un - objectionable \\
\hline 3 & Taste & Agreeable \\
\hline 4 & Turbidity (NTS) & $5 \mathrm{mg} / \mathrm{L}$ \\
\hline 5 & $\mathrm{pH}$ & $6.5-8.5$ \\
\hline 6 & Total hardness (as $\mathrm{CaCO}_{3}$ ) & 300 \\
\hline 7 & Alkalinity & $200 \mathrm{mg} / \mathrm{L}$ \\
\hline
\end{tabular}

\section{Results:-}

Physicochemical parameters of the water sample

The surface water temperature varied from $33^{\circ} \mathrm{C}$ to $37^{\circ} \mathrm{C}$. Temperature was found to increase with the depth of the source. Open well water had lower temperature than bore well water. $\mathrm{pH}$ values ranged from 6.83 to 7.2 . All the samples were colourless. The values for parameters such as alkalinity, salinity, hardness was within the limits as specified by ISI specifications for drinking water (table 4.1)

Table 3.1:- Physicochemical parameters analysed for the water sample.

\begin{tabular}{|c|c|c|c|c|c|}
\hline Sl. no. & Parameters & $\begin{array}{r}\text { Sample 1 } \\
\text { (Well water) }\end{array}$ & $\begin{array}{c}\text { Sample } 2 \\
\text { (Bore well) }\end{array}$ & $\begin{array}{c}\text { Sample } 3 \\
\text { (Maroli) }\end{array}$ & $\begin{array}{c}\text { Sample } 4 \\
\text { (Kadri) }\end{array}$ \\
\hline 1 & Temperature & $33^{\circ} \mathrm{C}$ & $34^{\circ} \mathrm{C}$ & $35^{\circ} \mathrm{C}$ & $37^{\circ} \mathrm{C}$ \\
\hline 2 & $\mathrm{pH}$ & 6.83 & 7.2 & 7.1 & 6.7 \\
\hline 3 & Colour & $\mathrm{CL}$ & $\mathrm{CL}$ & $\mathrm{CL}$ & $\mathrm{CL}$ \\
\hline 4 & Alkalinity $(\mathrm{mg} / \mathrm{L})$ & 0.65 & 0.30 & 1.0 & 0.95 \\
\hline 5 & Salinity $(\mathrm{mg} / \mathrm{L})$ & 0.2 & 0.26 & 0.33 & 0.27 \\
\hline 6 & Hardness (mg/L) & 22 & 22 & 37 & 16 \\
\hline 7 & $\mathrm{DO}(\mathrm{mg} / \mathrm{L})$ & $\begin{array}{l}\mathrm{D} 1-0.8 \\
\mathrm{D} 2-2.2\end{array}$ & $\begin{array}{l}\mathrm{D} 1-0.8 \\
\mathrm{D} 2-2.88 \\
\end{array}$ & $\begin{array}{l}\mathrm{D} 1-1.6 \\
\mathrm{D} 2-2.2 \\
\end{array}$ & $\begin{array}{l}\mathrm{D} 1-3.6 \\
\mathrm{D} 2-4.4\end{array}$ \\
\hline 8 & BOD $(\mathrm{mg} / \mathrm{L})$ & 1.4 & 2.0 & 0.6 & 0.8 \\
\hline 9 & $\mathrm{COD}(\mathrm{g} / \mathrm{L})$ & 0.0036 & 0.0065 & 0.0084 & 0.0074 \\
\hline
\end{tabular}

CL- colorless

\section{Most probable Number}

The results for the MPN test were determined from the MPN standard chart. Among the four samples analyzed well water had higher MPN index than the other samples. The Kadri water sample had the least value indicating safety of the water for human consumption (table 4.2, fig. 4.1).

Table 3.2:- MPN Results for the water sample compared to MPN standard chart.

\begin{tabular}{|l|l|c|c|c|c|}
\hline SI. No. & Samples & 3 of 10mL & 3 of 1 mL & 3 of 0.1 mL & $\begin{array}{c}\text { MPN (/100mL) Standard } \\
\text { chart }\end{array}$ \\
\hline $\mathbf{1}$ & Well water & 3 & 1 & 0 & 11 \\
\hline
\end{tabular}




\begin{tabular}{|l|l|l|l|l|c|}
\hline $\mathbf{2}$ & Bore water & 1 & 1 & 0 & 4 \\
\hline $\mathbf{3}$ & Maroli & 1 & 0 & 0 & 2 \\
\hline $\mathbf{4}$ & Kadri & 0 & 0 & 0 & $<2$ \\
\hline
\end{tabular}

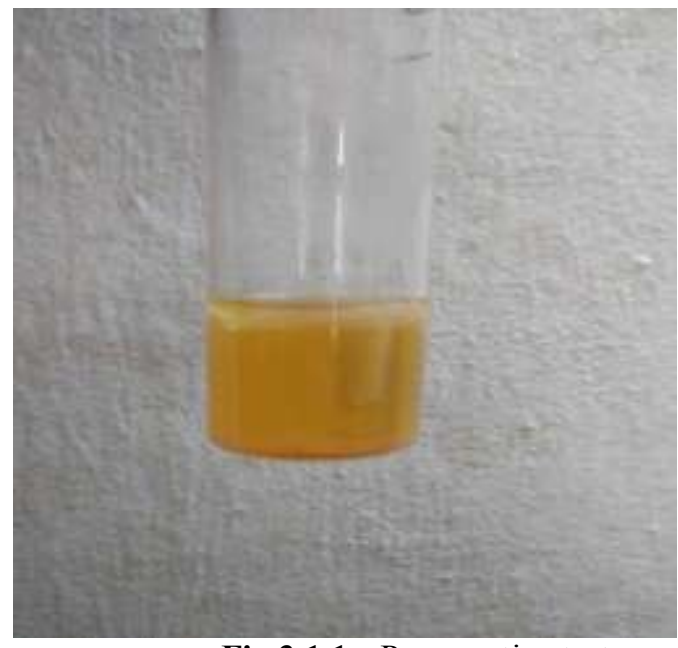

Fig 3.1.1:- Presumptive test.

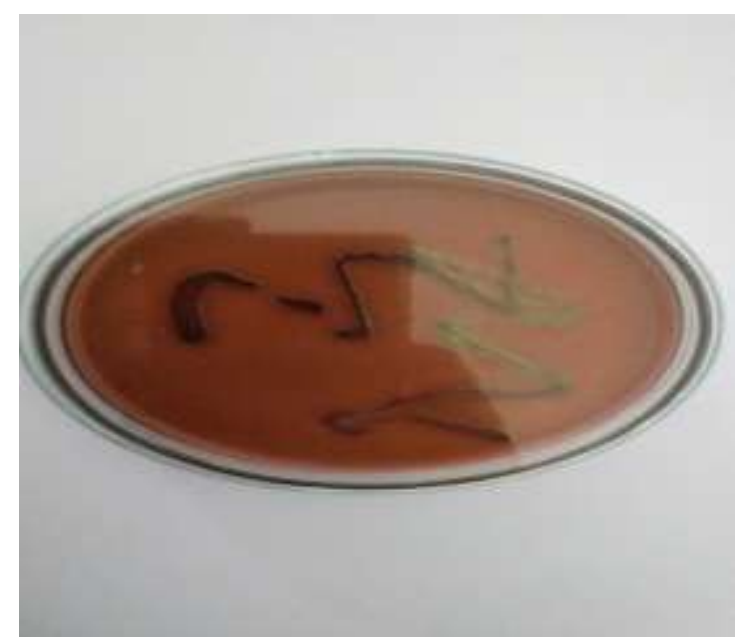

Fig 3.1.2:- Confirmed test.

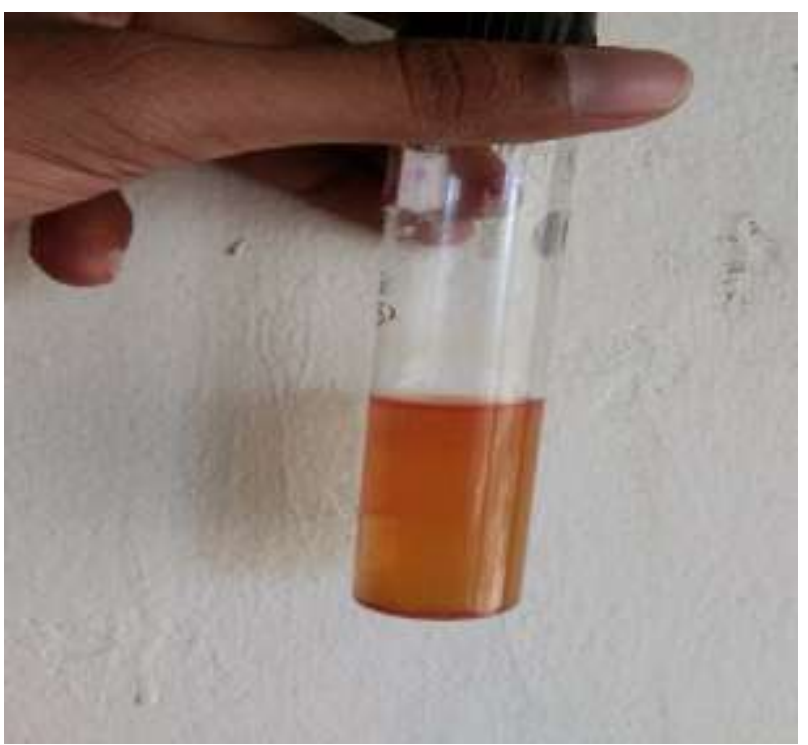

Fig3.1.3:- Completed test.

\section{Standard plate count}

Among the samples tested for safe human consumption, the well water sample had higher number of colonies i.e., $86 \mathrm{CFU} / \mathrm{mL}$ in $10^{-3}$ dilution and $47 \mathrm{CFU} / \mathrm{mL}$ in $10^{-5}$ dilution respectively. The least number of colonies were seen in bore well water (table 4.3, fig 4.2)

Table 3.3:- Standard plate count $(\mathrm{CFU} / \mathrm{mL})$ for the water samples.

\begin{tabular}{|l|c|c|c|c|c|}
\hline Sl. No. & Dilutions & SAMPLE 1 & SAMPLE 2 & SAMPLE 3 & SAMPLE 4 \\
\hline $\mathbf{1}$ & $10^{-3}$ & 86 & 21 & 63 & 32 \\
\hline $\mathbf{2}$ & $10^{-5}$ & 47 & 11 & 44 & 21 \\
\hline
\end{tabular}




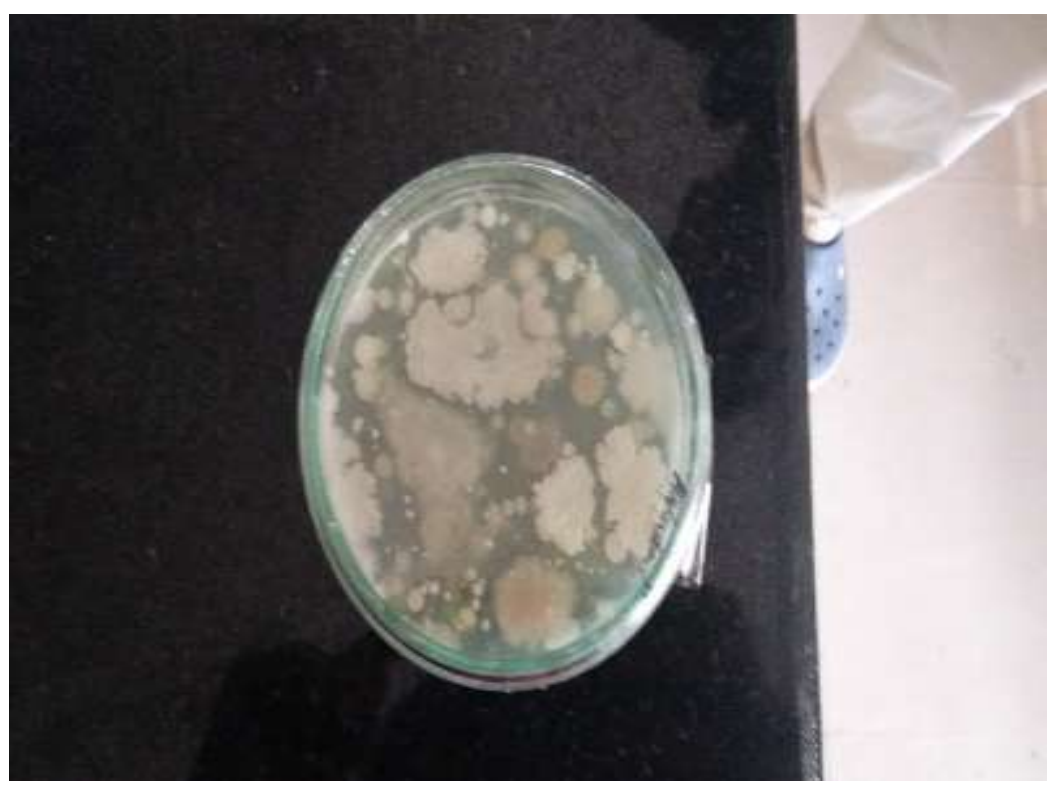

Fig. 3.2:- Standard Plate count method for water analysis.

\section{Discussion:-}

Life is possible because of water; hence use of water of good quality makes healthy life. However, physicochemical and biological properties of vary with sources of, types of water and geographical regions. There are certain chemicals present in water in higher or lower amount than the required ones similarly, there are number of pathogenic water borne protozoa, fungi, bacteria (Dubey et al., 2008).

Water microbiology is concerned with the microorganisms that live in water, or can be transported from one habitat to another by water. Water can support the growth of many types of microorganisms. This can be advantageous. For example, the growth of some bacteria in contaminated water can help digest the poisons from the water. However, the presence of other disease-causing microbes in water is unhealthy and even life threatening (Chapelle et al., 2000).

Drinking water is usually treated to minimize the risk of microbial contamination. The importance of drinking water treatment has been known for centuries. An important aspect of water microbiology, particularly for drinking water, is the testing of the water to ensure that it is safe to drink. Water quality testing can be done in several ways. In many countries, water microbiology is also the subject of legislation. Regulations specify how often water sources are sampled, how the sampling is done, how the analysis will be performed, what microbes are detected, and the acceptable limits for the target microorganisms in the water sample (Madigan et al., 2000).

Surface water and ground water samples were taken for various physico chemical parameters and biological parameters. The samples were collected from 4 different places in and around Mangalore using sterilized glass bottles in their respective environments and the bottles were brought back to laboratory for further analysis

Under aseptic conditions selected physico chemical parameters and biological parameters were being tested. The results obtained were compared with the ISI (Indian Standard Institute) specifications and the samples were evaluated for drinking water standards.

In the present study, the physicochemical parameters tested were in the range specified for drinking water standards. Along with this test; samples were serially diluted and tested for spread plate method using PDA and Nutrient agar. Samples were also analyses for MPN that indicates the presence of faecal contamination. However, in this study the values obtained in the MPN as well as SPC method indicates that the bacterial count in the well water is slightly higher than the other sources obtained. Therefore, regular methods such as boiling and purification of water before consumption should be suggested. 


\section{Conclusion:-}

In this study four different drinking water samples were collected from four different places. Two ground water samples and two surface water samples i.e., well water, bore well water as ground water samples and samples from Kadri and Maroli, Mangalore. Samples were tested for both bacterial and fungal growth by using pour plate methods with PDA and nutrient agar, observing number of colonies. The samples were tested for various physicochemical parameters and biological parameters and results were noted. The above obtained results were compared with the ISI (Indian Standard Institute) specification for drinking water. Thus, the given water samples when compared with ISI specifications can be said as eligible for drinking purpose, even though some samples had given positive results for MPN test it is advisable for drinking purpose with slight precautionary measures employed before drinking. 